JAIME BONET NAVARRO

Universidad de Valencia, Spain

\title{
THE INFLUENCE OF RELIGION IN THE TIME-RECKONING
}

\begin{abstract}
The advancement of humanity, which has culminated in artificial intelligence, cannot do without the measurement of time and the consequent existence of different calendars, such as the one used today, which has notable religious influences, as well as others with an even more deeply religious nature, such as the Muslim calendar. Starting from a reflection on the relationship among artificial intelligence, the fundamental right of religious freedom, and the various types of calendars, the study focuses on highlighting the religious influences which are inside the calendar used today throughout the world, their months and their days of the week. This calendar is based on the Roman calendar, which was reformed by Julius Caesar, and corrected centuries later, in the sixteenth century, by the reform carried out by Pope Gregory XIII. This is followed by a brief exposition of a purely religious calendar such as the Muslim one, as well as the frustrated attempts to establish secular calendars during the French and Russian revolutions, in the 18th and 20th centuries, respectively.
\end{abstract}

KEYWORDS: Calendar, calculation, religion, year, month, reckoning 


\section{INTRODUCTION: ARTIFICIAL INTELLIGENCE, RELIGION AND CALENDARS}

In a congress on „artificial intelligence and human rights” I am going to talk about religion in the calculation of time, because artificial intelligence is the most sophisticated technology, and the calendar and its reckoning is also an old technology, which requires the knowledge of very demanding scientist and technicians, especially in matters such as astronomy and mathematics, and which currently has great importance in the programming of any computer device or machinery, as well as in the social sphere (remember, for example, the fear of the „effect 2000 , a few year ago).

On the other hand, the daily experience based on a certain calendar is also, although not always consciously, an expression of the right to religious freedom, one of the human rights. So, in that sense, what happens to people belonging to groups religious with their own calendar who live in countries with a different official calendar, which can also be religious?

Regarding religious freedom as a fundamental right, it is recognized in Spanish regulations; thus art. 16 of the Spanish Constitution establishes that "the ideological, religious and religious freedom of individuals and communities is guaranteed” and that "the public powers will take into account the religious beliefs of Spanish society". Its legal development through Organic Law 7/1980, of 7 on Religious Freedom, among other issues, indicates that „religious and worship freedom guaranteed by the Constitution includes, with the consequent immunity from coercion, the right of every person to (...) commemorate their festivities". This legal mention includes, implicitly, the recognition of its own religious calendar in which said festivities are framed.

Furthermore, the cooperation agreements signed between Spain and the Jewish and Muslim religious communities include specific norms on the effective fulfillment of these issues.

Specifically, art. 12 of the cooperation agreement with Muslims (Law 26/1992, of November 10) mentions several months of the Muslim calendar, on the one hand, in paragraph 1, recognizing the possibility of ending the working day „one hour before the sunset, during the fasting month (Ramadan)”, and in paragraph 2 by indicating the festivities and commemorations that according 
to Islamic Law have the character of religious, which may replace the festivities officially established in Spanish legislation. They are the following ones: Al Hiyra, which corresponds to the first day of the month of Muharram, the first day of the Islamic New Year; Achura, tenth day of the month of Muharram; Idu al-Maulid, which corresponds to the 12th day of the month of Rabiu al Awwal, the birth of the Prophet; Al Isra Wa al-Mi'ray, which corresponds to the 27th day of the month of Rajab, the date of the Night Journey and the Ascension of the Prophet; Idu al-Fitr, which corresponds to the 1st to 3rd day of the month of Shawwal and celebrates the culmination of the Fast of Ramadan; and Idu al-Adha, which corresponds to the 10th to 12th of the month of Du Al-Hyyah and celebrates the sacrifice performed by Prophet Abraham.

Many questions arise in the thread of this argument, but I will focus on the religious component of our calendar and the attempts to replace it by alternative calendars of a secular nature that have been made along the history.

For example, the day June 11, 2021, is also the first day of the month of Tammuz in the year 5781 according to the Hebrew calendar, and it is the first day of the month of Du al-Qa'da of the year 1442 of the Muslim calendar. In effect, we are living the same day, today, but according to the calendar we use we will be in a year, a month and a different day number. And those calendars that I have mentioned, including the one that is accepted as universal, have a purely religious origin or with a high index of religious influence.

To begin with, the year 2021 is based on the assumption that Jesus Christ, the founder of the Christian Church, was born that same number of years ago and $\mathrm{He}$ is considered the Son of God by an approximate third of humanity. For this reason, and due to the conjunction of many historical, political, economic and cultural factors, it is the calendar that is held in common today, all over the world. The other mentioned calendars (Jewish and Muslim ones) may continue to have a more geographically localized or reduced influence on the believers of these religions. And these ones are not the only ethno-religious calendars in existence today, as there are also other religious or cultural calendars, such as the Chinese calendar, or the much less well-known Inuit or Eskimo calendar, or the former calendars of already extinct civilizations that are no longer valid today, but who had it in their day, such as, among others, the Mayan or Egyptian calendars (Borst, 1993; Westrheim, 1983; Parise, 1982, and Nilssonn 1920). 
Calendars have been and still are of many types. Some of them, the socalled phenological calendars, such as the Inuit one, focus on observing nature; so, in this case, it simply takes into account the number of hours of daylight throughout the year.

However, most calendars start from the observation, since immemorial times, of the evolution of the stars (as the astrological calendars), which, in turn, are distinguished in: a) solar calendars (like ours, the one used mostly in today's world) that follow the cycle of the Earth around the Sun, in which the seasons correspond to the same months of the year; b) lunar calendars (such as the Muslim one), in which the months follow the 28-day lunar cycle, and which "rotate" through the different seasons of the year and only coincide every 33 years, or c) a combination of both (the lunisolar calendars), such as, among others, the Jewish calendar, or the Catholic liturgical calendar itself (Pedersen, 1983), which, being basically a solar one, it contains some festivals with a lunar cycle, such as Easter, which is celebrated on the first Sunday after the first spring new moon, and associated festivals such as Ash Wednesday and the Feast of the Ascension.

\section{THE CALENDAR USED AS UNIVERSAL IN TODAY'S WORLD ("OUR CALENDAR")}

When I say „our calendar”, I mean the Gregorian calendar, which has that name because it was Pope Gregory XIII who established it in 1582, with the Bull „Inter Gravissimas” (Ziggelaar, 1983). This pope modified the calendar followed until then, the Julian calendar, which was established, and hence its name, by Julius Caesar. 


\section{THE JULIAN CALENDAR}

Julius Caesar reformed the former Roman calendar in the year $46 \mathrm{BC}-$ before Christ-, or year $708 \mathrm{Ab}$ urbe condita - since the foundation of the city of Rome-, which was the initial moment of the reckoning of the Roman calendar. The Julian reformation of the preceding Roman calendar had the help of Greek mathematicians and astronomers such as Sosigenes of Alexandria (Brind'Amour, 1983, and Michels, 1967).

In the Roman calendar prior to the reform of Julius Caesar, the ordinary year had 12 months for a total of 355 days, and sometimes an intercalary month of 27 or 28 days was inserted (the Mensis Intercalaris, between February and March), It is due to the fact that the Roman year, until the year $153 \mathrm{~b}$. C, it started on March 1 . The intercalary month was formed by adding 22 or 23 days after the days of February. The ideal intercalary cycle consisted of ordinary years of 355 days alternated with intercalary years, alternately 377 and 378 days long. Thus, the average Roman year would have 366 days and a quarter for a period of four years, and in a more precise way, introducing three intercalary years every eight years, the average length of the year in a period of 25 years would be an amount of only 365 and a quarter. But this ideal intercalary average did not always occur because these intercalary months were introduced by decision of the highest Roman authority, who made the decision according to his political convenience, or to favor someone by prolonging his mandate or, on the contrary, to harm someone who was considered unpleasant by preventing him from enjoying the intercalary month during his mandate. These abuses made the Roman years prior to the introduction of the Julian calendar were called „years of confusion”.

Julius Caesar's reform aimed to solve this problem permanently. To achieve that purpose, his calendar would stay aligned with the Sun without any human intervention, and he combined the ancient Roman months into a year of 365 days and a quarter of duration, which meant, over time, the addition of an extra day every four years. Previously, 85 extra days had to be added to the year $46 \mathrm{BC}$.

The name of most of the months of the Roman calendar, before and after the reform of Julius Caesar, honoured, direct or indirectly, Roman gods such 
as the god Janus, the god of two faces, the god or doors, gates, beginnings and endings, in the month of January (Januarius in Latin), in the month that opens the year. The month of March (Martius in Latin) honors the god Mars, god of war, due to this month was the one in which the Romans planned and gestated their military campaigns, the consuls usually offered the rites in this month and marched with their armies to war. The month of May (Maius in Latin) honors the goddess Maia, one of the oldest goddesses in Rome and who was a goddess of spring, and some sacrifices to her were offered on the first of May. The month of June (Iunius in Latin) honors the goddess Juno, goddess of marriage, wife of Zeus and queen of the gods.

These months take its names, directly, from the name of Roman gods or goddess. Some other months take its name from rituals or festivals dedicated to some gods, such as February (Februarius in Latin) which comes from Februo, which means "to cleanse oneself”, since in February the Romans performed certain religious rites and rituals dedicated to the god Pluto intended to achieve purity, and April (Aprilis in Latin) which name comes from "aperio", which means to open, since it is when the plants begin to bloom, and it is also pointed out that it may also be taken from the Greeks who dedicated it to the goddess Aphrodite, Venus for the Romans.

Initially, the Roman year began in March, and had only ten months: Martius, Aprilis, Maius, Junius, already mentioned, and Quintilis, Sextilis, Septembris, Octobris, Novembris, and Decembris, although from 713 a. C., King Numa Pompilio, successor of Romulus, he added the months of Januarius and Februarius, to match the calendar to the seasons of the year. So, our September, which name means the seventh, is really the nineth in our calendar, and so on, October is not the eight but the tenth, November is the eleventh and not ninth, and the last one, December is not the tenth but the twelfth.

Julius Caesar himself named after him the fifth month (Julius), and later, Augustus did the same with the sixth (Augustus).

In the same way, several of the days of the week take his name from Roman gods, such as Tuesday, Martis dies in Latin, 'the day of Mars', like the month of March («martes» in Spanish and «martedi» in Italian); Wednesday, Mercuri dies in Latin, 'the day of Mercury' («miércoles» in Spanish and «mercoledi» in Italian); Thursday, Iovis dies in Latin, 'the day of Jupiter or love' («jueves» 
in Spanish and «giovedi» in Italian); Friday, Veneris dies in Latin, 'the day of Venus' («viernes» in Spanish and «venerdi» in Italian), and Saturday, Saturni dies in Latin, 'the day of Saturn'. However, the name of this day, in Spanish and Italian («sábado» and «sabato»), under the influence of Christianity it was changed to Sabbath, the day of rest among the Jews.

Finally, the Monday, Lunae dies in Latin, 'the day of the Moon' and Sunday, Solis dies in Latin, 'the day of the Sun', they don't have a name from a god bur from stars. Also, the name of Sunday, in Spanish and Italian, it was also changed to Dominican day, the Lord's Day: «domingo» and «domenica».

The Julian calendar was extended beyond the borders of the Roman Empire by its use by the Christian liturgical calendar, because when a people or a country was converted to Christianity, it also adopted that calendar, and marked the reckoning of time throughout the Christian world. until its reform by Gregory XIII; moment from which it was only followed by the Orthodox Church (Hoskin, 1983).

\section{THE GREGORIAN CALENDAR REFORM}

The reform of the calendar was promoted by Pope Gregory XIII with the intention of correcting the inaccuracy of the Julian calendar, which, with a year of 365.25 days, did not correspond exactly to the actual duration of the year, since the actual translation of the Earth around the Sun (or tropic year) is $365^{\prime} 242189$ days.

That eleven-minute lag from the times of Julius Caesar, with the passing of the centuries, reached ten days, which came to pose a problem to fix the Easter festival, and stopped corresponding with the seasons of the year. The entry into force of the Gregorian calendar meant the elimination of those ten days, and after Thursday, October 4, 1582 (in Julian calendar) came Friday, October 15, 1582 (already Gregorian calendar).

Also, Pope Gregory fixed the date of January 1 definitively as the starting day of the year, since until then, in some places of Christendom, the first day of the year was, in addition to that day, December 25 (Christmas), or on March 25 (day of the Incarnation). 
He also more precisely defined the system of leap years (366-day years), which would be all years multiple of 4 (as in the Julian calendar) except for multiples of 100 (as 1700, 1800, 1900...) which would not be leap years and with another correction: if those years, in addition to being multiple of 100 , they are also multiple of 400 (as 1600, 2000, 2400...) they would be leap. Thus, the Gregorian year lasts 365.2425 days, a very close figure to the actual tropical year. The mismatch is so small that it will only be relevant in about 3300 years. Therefore, in ten thousand years, the Gregorian calendar will have three days too many(Russo, 1983, p. 290-291).

Our calendar, in addition to having been reformed by the supreme authority of a religious confession such as the Catholic Church: it also begins the calculation of the years since the birth of the founder of the Christian religion, and has the usual weekly rest in the seventh day, Sunday, 'the Lord's day' (dies Dominis in Latin). For this reason, its religious imprint has been blurred by ignoring the mentions «before Christ» (BC) or «after Christ» (AC) typical of the so-called «Christian Era» (Pedersen, 1983, p. 49-54), for alternatives such as «common Era» and «before the common Era», even keeping the date of Christ's birth as a determining factor.

\section{The Muslim CALENDAR: AN EXAMPLE OF RELIGIOUS CALENDAR}

The Muslim calendar begins its computation from the Hegira, which is the name given to the emigration of the Prophet and his followers from Mecca, where their new religion was not accepted, to the town of Yathrib (since then called Medina), on September of 622. The word «Hijra», in Arab, literally means 'migration', and not 'flight', but sometimes by mistake they translate it that way. In 637 (15 years after the Hegira) the Caliph Umar instituted it as the starting point of the Islamic Era.

By the other hand, the Muslim calendar is based on the lunar or synodic month, which is the time it takes for the Moon to circle the Earth, that is, 29 and a half days, that is, the time that elapses between one new moon and the next. 
The Muslim lunar year consists of 12 months: Muharram, «Safar», «Rabi'alAwwal», «Rabi ,al-Thani», «Yumada al-Wula», «Yumada al-Thania», «Rayab», «Sha’aban», «Ramadan», «Shawwal», «Du al-Qa'da» and «Du al-Hijjah». Five of those months are 29 days and the rest 30, so the total is a year of only 354 days. According to Climent, „the names of the months, some of which refer to the seasons, have their origin in the pre-Islamic Arabic calendar, which originally added a month every three years, in order to keep the lunar calendar in harmony. with the seasons" (Climent). However, the current Islamic calendar does not take into account the old triennial correction, so that, each year, it accumulates a difference of 10 or 11 days per year with respect to the solar calendar, and as a consequence, the Muslim months gradually shift through the seasons in such a way that the same month falls in different seasons in a thirty-three-year cycle.

\section{THE UNSUCCESSFUL ATTEMPTS TO REPLACE THE GREGORIAN CALENDAR BY SECULAR ONES}

Beyond this, at certain times, the Gregorian Calendar has been replaced by a secular calendar, lacking religious elements and with the intention of making it difficult to celebrate holidays or weekly breaks linked to religion, as did the French Republican and Soviet Revolutionary calendars, which turned out to be short-lived experiences.

\section{THE FRENCH REPUBLICAN CALENDAR}

In the French Republican calendar (Shaw, 2011) the year begins with the autumnal equinox, the first of the month named Vendémiaire (September 22). The names of the twelve months of the year are neologisms related to nature and agriculture. "Vendémiaire» comes from Latin vindemia, 'vintage', the grape harvest during September and October, and successively, «brumaire» (from the French brume, ,mist') and «frimaire» (from French frimas, ,frost') complete the autumn months: «nivôse» (from Latin nivosus, ,snowy'), «pluviôse» (from Latin pluviosus, ,rainy') and «ventôse» (from Latin ventosus, 
,windy') are the winter ones; «germinal» (from Latin germen, ,seed'), «floréal» (from Latin flos, ,flower') and «prairial» (from the French prairie, ,meadow'); and the summer months, wich are «messidor» (from Latin messis, 'harvest'), «thermidor» (from the Greek thermos, 'heat0) and «fructidor» (from Latin fructus, 'fruit') with which the year ends.

Such 30-day months are divided into three ten-day periods (or decades). The names of the days are not associated with Roman stars or gods, but rather with their order: «primidi» (first day), «duodi» (second day), etc., until «décadi» (tenth day), and with secularizer spirit, instead of with saints, they relate them to plants, flowers, minerals, animals (days ending in 5) or tools (the ones ending in 0 ).

It was in force for about 13 years, between 1792 and 1805, when Napoleon abolished it, for various reasons: 1) Astronomically it was an out of phase calendar of the lunar cycle of 28 days (four weeks) and it did not solve the problem of leap years. 2) It complicated international relations as the rest of Europe continued with the Gregorian calendar. 3) It was in accordance only with the French climate and nature, and it was hardly exportable to other countries, and it was impossible to be applied to other latitudes (Southern Hemisphere). 4) The Catholic Church opposed the abolition of Sunday. 5) The ten-day week disliked the workers for leaving less rest as there was only one party every ten days. 6) The 30-day months required five (or six in leap years) days to complete the 365 days that the solar cycle lasts: the year ended on September 16 (fructidor 30) but the new one began on September 22 (first day of Vendémiaire). Those days, called «sansculottides» celebrated virtue, talent, work, opinion, rewards and the Revolution, but it was only a holiday on the last day, as it was a time of great agricultural work. For this reason, in 1805 the seven-day week was reintroduced, as a previous step to its abolition, and the Gregorian calendar returned to France on January 1, 1806. 


\section{The Soviet Revolutionary CALENDAR}

On the other hand, the Soviet Revolutionary calendar, also known as Eternal Calendar (Wenjaminowitsch and Samoilowitsch, 1989) was used in the USSR from October 1, 1929 to 1940. Proposed by the economist Yuri Larin, it intended to encourage industrial production based on a rational distribution of the off work days, which were no longer simultaneous for all workers. Thus, each month, of 30 days, was integrated for six weeks of five days, with a different colour for each day (yellow, pink, red, purple and green), and the workers of the various economic activities were organized into five groups, which were assigned a colour as a day of rest. Thus, the USSR would always have active workers, in some sector of the economy, every day of the year.

Soviet calendar had twelve months, with 30 days each of them. So, 5 remaining days were added to complete the year of 365 days. These days, which did not belong to any month (technically known by the name of epagomenal days), were (according to the dates of the Gregorian calendar): January 22 (Bloody Sunday and commemoration of Lenin's death); May 1 and 2 (The International days), and November 7 and 8 (October Revolution Days). In leap years, an extra day was added after February 30.

With this calendar, Sunday was abolished and the observance of traditional religious festivities was also made difficult, without being totally successful, since the observance of the Julian calendar and the weekly rest on seventh day (Sunday) was maintained in parallel, especially in rural areas. and by the Russian Orthodox Church.

Despite the fact that Soviet workers had more days off (one in five, instead of one in seven, which supposes a sum of 72 instead of the old 52 Sunday breaks) it was unpopular because the separation of the proletariat into five groups did more daily life difficult at the social and family levels, and also, for the coordination of activities between workers of different economic activities, and furthermore, it did not produce economic benefits, nor did it increase productivity or save on raw materials or hours of work (Foss, 2004, p. 46-47).

On December 1, 1931, the Soviet government decided to return to the traditional length of months $(31,30$, or 28 days), and a new "six-day week" was implemented, with a weekly rest day. common for the entire population. 
So, the Gregorian calendar, with the traditional length of months, returned in 1934, but the seven-day week was not reinstated until 1940.

In addition to the lay calendars that came to be applied effectively, many other calendars have been proposed, such as Elisabeth Achelis's World Calendar (dating back to the 1930s), based on a twelve-month year, such as the Bonavian Calendar (from Carrier, 1970), Alphabetic (from da Costa, 2002), Ecliptic (from Scott, 2002), or Symmetric (from Bromberg, 2004), among others (see Home Page for Calendar Reform).

\section{Conclusion}

The calendar that organizes and on which we base our lives, like so many other facets of the world in which we live, such as our organization as a society, our customs, and ways of life, are steeped in religious elements or influences. This calendar, used today in most of the countries of the world, is based on the Roman calendar, which already has an undeniable religious component, later increased after the reform of Pope Gregory XIII. And there are a lot of other religious calendars such as Muslim or Jewish ones. Which are recognized, even if in a more limited way, for being part of their respective beliefs, which must be taken into account because they form part of the content of the fundamental right to religious freedom. The attempts to achieve its secularization have failed, at least in its formal aspect, as has happened with the frustrated attempts to implant secular or strictly secular calendars. 


\section{REFERENCES}

Borst, A. (1993). The Ordering of Time: From the Ancient Computus to the Modern Computer. Polity Press.

Brind'Amour, P. (1983). Le Calendrier romain: Recherches chronologiques. Éditions de l'Université d'Ottawa

Climent, D. El calendario musulmán y el Ramadán, in https://epdf.pub/el-calendario-musulman-y-el-ramadan.html.

Foss, C. (2004) Stalin's topsy-turvy work week. 54, 46-47. History Today.

Gingerich, O. (1983), The Civil Reception of the Gregorian Calendar, in Coyne, G. V., Hoskin, M. A. and Pedersen, O. (ed.), Gregorian Reform of the Calendar: Proceedings of the Vatican Conference to Commemorate Its 400th Anniversary 1582-1982, 265-279. Specola Vaticana.

Home page for Calendar Reform, The World Calendar, in http://myweb.ecu.edu/ mccartyr/calendar-reform.html.

Hoskin, M. A. (1983), The Reception of the Calendar by Other Churches. in Coyne, G. V., Hoskin, M. A. and Pedersen, O. (ed.), Gregorian Reform of the Calendar: Proceedings of the Vatican Conference to Commemorate Its 400th Anniversary 1582-1982, 255-264. Specola Vaticana.

Michels, A. K. (1967). The Calendar of the Roman Republic. Oxford University Press.

Nilssonn, M. P. (1920). Primitive Time-Reckoning: A Study in the Origins and First Development of the Art of Counting Time among the Primitive and Early Culture Peoples. C.W.K. Gleerup.

Parise, F. (1982). The Book of Calendars. Gorgias Press.

Pedersen, O. (1983). The Ecclesiastical Calendar and the Life of the Church. in Coyne, G. V., Hoskin, M. A. and Pedersen, O. (ed.), Gregorian Reform of the Calendar: Proceedings of the Vatican Conference to Commemorate Its 400th Anniversary 1582-1982, 17-74. Specola Vaticana.

Peter, B. Kalender und Zeitrechnung: Der Sowjetische "Ewige” Revolutionskalender, in http://www.kultur-in-asien.de/Kalender/seite494.htm.

Russo, F. (1983). Contemporary Discussions on the Reform of the Calendar. in Coyne, G. V., Hoskin, M. A., and Pedersen, O. (ed.), Gregorian Reform of the Calendar: Proceedings of the Vatican Conference to Commemorate Its 400th Anniversary 1582-1982, 287-298. Specola Vaticana.

Shaw, M. (2011). Time and the French Revolution, The Republican Calendar 1789-Year $X I V$. Royal Historical Society.

Weniaminowitsch, A., and Samoilowitsch, M. (1989). Ewige Kalender. Leipzig Teubner Verlagsgesellschaft.

Westrheim, M. (1983). Calendars of the World: A Look at Calendars \& the Ways We Celebrate. Oneworld Publications.

Ziggelaar, A. (1983). The Papal Bull of 1582 Promulgating a Reform of the Calendar. in Coyne, G. V., Hoskin, M. A. and Pedersen, O. (ed.), Gregorian Reform of the Calendar: Proceedings of the Vatican Conference to Commemorate Its 400th Anniversary 1582-1982, 201-239. Specola Vaticana. 
